\title{
Mandenkan
}

MANDENIKAN Bulletin semestriel d'études linguistiques mandé

$50 \mid 2013$

Numéro 50

\section{Interacting tonal processes in Susu}

Des phénomènes tonals en soussou

ВЗАИМОДЕЙСТВИЕ ТОНАЛЬНЫХ ПРОЦЕССОВ В СУСУ

\section{Christopher R. Green, Jonathan C. Anderson and Samuel G. Obeng}

\section{(2) OpenEdition}

\section{Journals}

Electronic version

URL: https://journals.openedition.org/mandenkan/876

DOI: $10.4000 /$ mandenkan.876

ISSN: 2104-371X

\section{Publisher}

Llacan UMR 8135 CNRS/Inalco

\section{Printed version}

Date of publication: 1 December 2013

Number of pages: 61-84

ISSN: 0752-5443

\section{Electronic reference}

Christopher R. Green, Jonathan C. Anderson and Samuel G. Obeng, "Interacting tonal processes in Susu", Mandenkan [Online], 50 | 2013, Online since 01 December 2013, connection on 08 July 2021. URL: http://journals.openedition.org/mandenkan/876 ; DOI: https://doi.org/10.4000/mandenkan.876

This text was automatically generated on 8 July 2021.

\section{(c) (i) (2) (2)}

Les contenus de Mandenkan sont mis à disposition selon les termes de la Licence Creative Commons Attribution - Pas d'Utilisation Commerciale - Partage dans les Mêmes Conditions 4.0 International. 


\section{Interacting tonal processes in Susu}

Des phénomènes tonals en soussou

ВЗАИМОДЕЙСТВИЕ ТОНАЛЬНЫХ ПРОЦЕССОВ В СУСУ

Christopher R. Green, Jonathan C. Anderson and Samuel G. Obeng

\section{AUTHOR'S NOTE}

\section{List of Abbreviations}

$\mathrm{A}=$ adjective

AFF = affaissement; settling

cf. $=$ confer

$\mathrm{C}=$ consonant

$\mathrm{CT}=$ compacité tonale

$\mathrm{f} .=$ female

$\mathrm{H}=$ high tone; $\dot{v}$

$\mathrm{L}=$ low tone; $\grave{\mathrm{v}}$

nb. = note well; nota bene

$\mathrm{M}=$ modifier

$\mathrm{N}=$ noun

$\mathrm{NBC}=$ neutralization-by-copy

$\mathrm{pl}=$ plural

$\mathrm{RAI}=$ tone raising

$\mathrm{TBU}=$ tone bearing unit

$\mathrm{V}=$ vowel

$\mathrm{X}=$ represents any tone; high or low

We would like to thank audience members at ACAL 42, Michelle Morrison, Valentin Vydrine, and two anonymous reviewers for helpful comments and challenging suggestions on earlier versions of this work. 


\section{0 . Introduction}

1 This paper takes as its point of departure a discrepancy in the Susu (Soso, Sosokhui, ISO: sus) tonology literature related to tone in nominal compounds (e.g. Houis 1963; Grégoire 1978; Touré 2004) and aims to advance the dialogue on Susu tone by considering the role that interacting tonological processes play in generating the surface tonal melodies in these and related constructions. While the data below may not be exhaustive, they bring to light the tonal behavior of wider variety of nominal constructions (e.g. more word shapes) that are not explored in detail in the Susu literature. By viewing these new data alongside what has been previously reported for Susu, we aim to better understand how tonal processes interact in the language.

2 We first provide background on Susu tone and the tonal melodies of singular and plural nouns, as well as nominal compounds. We then consider, for comparison, the surface tonal melodies resulting from the addition of certain modifiers to a noun. Our results illustrate that while the tonal melodies of Susu nominal constructions are neutralized or 'tonally compact' (Grégoire 1978), the transparent outcome of Susu tonal neutralizations is obscured in some instances as a result of other tonal processes.

The remainder of this paper is organized as follows: Section 1 provides additional background on Susu nominal tonology. Section 2 discusses tonal manipulations found in more complex nominal constructions in the language. Section 3 discusses the tonal properties of some noun+modifier constructions. Sections 4 and 5 offer discussion and a brief conclusion.

\section{Basics of Susu nominal tone}

Previous work on Susu (e.g. Grégoire 1978; Houis 1963; Touré 1994, 2004) converges on the fact that mono- and disyllabic nouns, generally speaking, have one of three distinct tonal melodies, namely H, HL, and LH. ${ }^{2}$ These melodies, depending on context and the particular construction, often differ from their proposed underlying forms. Consider in (1) the representative examples of disyllabic nouns with three different underlying tonal melodies in isolation.

\begin{tabular}{|l|l|l|l|l|}
\hline (1) & \multicolumn{4}{|l|}{ Underlying and surface tonal melodies } \\
\hline & a. & $/ \mathrm{HH} / \rightarrow$ & {$[$ túlíi } & 'ear' \\
\hline & b. & $/ \mathrm{HL} / \rightarrow$ & {$[$ kérì] } & 'hoe' \\
\hline & c. & $/ \mathrm{LH} / \rightarrow$ & {$[$ ğìṅ̀] } & 'woman' \\
\hline
\end{tabular}

5 It is yet unclear, analytically and theoretically, how and why these melodies behave in the ways that they do in all instances. For example, while underlying 'all L' melodies are not reported, surface 'all-L' sequences are common. In (1a,b), HH and HL tonal melodies surface as expected, yet a /LH/ melody surfaces [LL] in pre-pause and phrasefinal positions (1c), as well as in other contexts detailed in \$2. We discuss below analogous instances where underlying / $\mathrm{HL} /$ words have a surface $[\mathrm{HH}]$ melody. 
Surface tonal melodies also change according to context, e.g. before the plural suffix. This suffix in Susu is historically -ỳं; however it is manifested in different ways in contemporary Susu. Segmentally, when -ye is added to a vowel-final stem, a derived long vowel results, and the quality of this vowel varies according to the nature of the stem final vowel. The plural of the nouns from (1) is given in (2).

\begin{tabular}{|l|l|l|l|l|}
\hline (2) & \multicolumn{4}{|c|}{ Pluralization with basic tonal melodies } \\
\hline & a. & túlí + -yè $\rightarrow$ & [túléè] & 'ears' \\
\hline & b. & kérì + -yè $\rightarrow$ & [kérèè] & 'hoes' \\
\hline & c. & gìné + -yè $\rightarrow$ & [gìnéè] & 'women' \\
\hline
\end{tabular}

7 The tonal melodies for $\mathrm{HH}$ and $\mathrm{HL}$, again, surface as expected. For (2a), when the $\mathrm{L}$ tone plural suffix is added to the lexically HH word, a falling tone results on the long vowel. When the suffix is added to the lexically HL word in (2b), the result is a long L vowel. The outcome in (2c) is different. Recall from (1c) that this word has a lexical LH melody, but in isolation, [LL] results. Example (2c) shows that when the environment for phrase-final $\mathrm{H}$ tone lowering is removed, the lexical melody of the word re-emerges. Thus, in (2c), the plural counterpart of a lexically LH word has a falling tone on its final long vowel.

Other melodies (e.g. HLH and LHL) are possible for trisyllabic nouns and nouns with phonemic long vowels in different positions. This is because the Susu tone bearing unit (TBU) is the mora (Vydrine 2002), rather than the syllable. Due to their more complex structure, such nouns defy basic tonal melody patterning. Consider the disyllabic, lexically L $\overparen{H L}$ noun in

\begin{tabular}{|c|c|c|c|c|c|}
\hline (3) & a. & /yغ̀xर̂:/ & $\rightarrow$ & [yèxé $\left.{ }^{\mathrm{L}}\right]$ & 'sheep' \\
\hline & b. & yèx $\varepsilon^{L}+$-yè & $\rightarrow$ & [yèxéč] & 'sheep (pl.)' \\
\hline
\end{tabular}

9 (3a) has an underlying long vowel in its final syllable; however lexical vowel length contrasts are typically neutralized word-finally. The final L of the word's lexical tonal melody is not expressed on the shortened vowel and instead floats at the right edge of the word. The floating $\mathrm{L}$ tone blocks the usual environment for final $\mathrm{H}$ tone lowering (cf. 1c). In (3b), the final, derived long vowel is due to the addition of the plural morpheme. Although removed from final position, the lexical length contrast of the stem-final vowel is analogously neutralized, presumably because Susu avoids creating trimoraic, superheavy syllables. With these basic properties of Susu tone as a starting point, we turn to its tonal behavior in more complex contexts.

\section{Tone in nominal constructions}

Tonal neutralization in compounding and noun phrase construction is common and generally falls into one of two main categories in Mande languages. The first of these, 
compacite tonale (CT: also known as the noun-compounding rule or tonal compactness), is well-attested in Manding languages, among them Maninka, Bambara, and Dyula (e.g. Courtenay 1974; Creissels 1992; Creissels \& Grégoire 1993; Creissels 2009; Dumestre 1987; Green 2010, 2013; Leben 1973; Sanogo 1995). A second type is found in Southwest Mande languages, including Mende (e.g. Dwyer 1971, 1978a, 1978b; Spears 1967), and Zialo (Babaev 2010). Analogous processes are described for dialects of Vai (Welmers 1976), Kpelle (e.g. Konoshenko 2009) and LoJma (e.g. Mishchenko 2009; Sadler 2006; Vydrine 1989). ${ }^{3}$

11 These analogous processes effectively neutralize the lexical tonal melody of one or more elements of a phrase. The mechanism, inventory of tonal outcomes, and types of phrases that trigger and/or exhibit neutralization are language specific, yet the melodies that result are largely predictable in a given language. We adopt the position here that these neutralizations (and processes related to them) are reflexes of a crosslinguistic tendency for languages to smooth the tonal contour of words and phrases (Hyman 1978, 2007).

Similar tonal neutralizations are also found in Central Mande languages outside of Manding, e.g. in Susu (Grégoire 1978; Houis 1963; Touré 1994) and in Dialonké (Keita 1989). While Grégoire (1978), Touré (1994), and Keita (1989) refer to these neutralizations as compacité tonale, we discuss below that the processes in Susu and Dialonké (and indeed in Southwest Mande) are quite different from CT in Manding. Nonetheless, we take as a starting point Grégoire (1978), which focused on the behavior of tone in Susu noun+noun compounds. Grégoire expands upon and partially confirms findings in Houis (1963) on this topic, including that tonal neutralization occurs in Susu nominal compounding. Houis (1963) and Grégoire (1978), however, do not agree on all the details. We discuss their findings alongside our own in $\$ 2.2$.

\subsection{Tone neutralization exemplars}

In order to set the stage for comparison to Susu, we first present examples of tonal neutralization in two exemplars, Bambara and Mende. There are two typical results of $\mathrm{CT}$ in the representative Bambara nominal compounds in (4). This neutralization is also often characteristic of other constructions, e.g. noun+modifier.

\begin{tabular}{|l|l|l|l|l|l|}
\hline (4) & \multicolumn{4}{|l|}{ CT in Bambara nominal compounds } \\
\hline & a. & High melody compactness: & [básá] + [wòló] & $\rightarrow$ [básáwóló] ‘lizard skin’ \\
\hline & & & \multicolumn{2}{l|}{ lizard + skin } \\
\hline & b. & Low melody compactness: & [jàrá] + [wòló] & $\rightarrow$ [jàràwóló] ‘lion skin’ \\
\hline & & & \multicolumn{3}{l|}{} \\
\hline & c. & Compactness in longer constructions: \\
\hline & & & [jàkúmá] & + + [wòló] & $\rightarrow$ [jàkùmàwóló] 'cat skin’ \\
\hline & & & cat skin & \\
\hline
\end{tabular}


In these and other instances of Bambara CT, the resultant tonal melody of the compound depends upon the lexical tonal melody of the first element of the construction. ${ }^{4}$ In constructions like (4a), the $\mathrm{H}$ tone of the first element dictates that the resultant melody of the compound is 'all- $\mathrm{H}$ ', regardless of the lexical tonal melody of the second input lexeme. In instances like (4b), the L tone of the first element dictates an alternative outcome. Here, upon compounding, the lexical $\mathrm{L}$ tone of the first element spreads rightward, creating an 'all-L' melody on the first morpheme followed by a default, 'all-H' melody on the second morpheme, regardless of the input tonal melody of the second lexeme. This spreading is not restricted to a single TBU. The process also occurs in longer words like (4c). ${ }^{5}$

15 A second type of neutralization is found in Mende, as in (5); examples are drawn from Spears (1967). We include proposed lexical tone patterns for each element, as they are key to illustrating the tonal outcome of the resulting construction. The tonal melody of the constructed noun phrase is approximated from Spears' illustrations which intend to show phonetic tone.

\begin{tabular}{|c|c|c|c|c|}
\hline \multirow[t]{2}{*}{ (5) } & \multicolumn{4}{|c|}{$\mathrm{CT}$ in Mende attributive modifier noun phrases } \\
\hline & a. [bèlè ] + [nìnă] & $\rightarrow$ & [bèlè-nìnà] & 'new trousers' \\
\hline & b. [gbèhć $]+[$ nìnǎ] & $\rightarrow$ & [gbèhé-nínà] & 'new stool' \\
\hline & c. [pélḱ] + [nină] & $\rightarrow$ & [pélé-nínà] & 'new house' \\
\hline & d. [ndòmǎ] + [nìnǎ] & $\rightarrow$ & [ndòmà-nínà] & 'new shirt' \\
\hline & e. [pùndi] + [nìnǎ] & $\rightarrow$ & [pùndí-nìnà] & 'new mosquito \\
\hline & f. [kôwù] + [nìnǎ] & $\rightarrow$ & [kówù-nìnà] & 'new box' \\
\hline & g. [bâ] + [nìnǎ] & $\rightarrow$ & [bá-nìnà] & 'new price' \\
\hline
\end{tabular}

These representative examples of Mende tonal neutralizations can be explained straightforwardly. For each, the lexical tonal melody of the first (nominal) element is almost entirely maintained, except in instances involving a proposed underlying tonal contour associated with a single TBU, while that of the second (adjectival) element is neutralized. The general phenomenon characterizing Mende tonal neutralization is as follows: the final lexical tone of the first element is copied or shared (to use Spears' term) to the first TBU of the second element, while the lexical tones of the second element are overwritten by $\mathrm{L}$ tones. ${ }^{6}$ Thus, the final lexical $\mathrm{H}$ of the input noun in $(5 b, c, d)$ lands on the first TBU of the adjective, while the final lexical $L$ of the input noun in $(5 \mathrm{a}, \mathrm{e}, \mathrm{f}, \mathrm{g})$ is shared by the same mechanism. Thus, there are two possible tonal outcomes ( $\mathrm{HL}$ or $\mathrm{LL}$ ) on the second morpheme in each example in (5) as a result of it being preceded by elements ending with different lexical tones. ${ }^{7}$

There are theoretical implications to consider depending on whether one assumes that tones are shared vs. copied in Southwest Mande (and as we shall discuss below, in Susu) neutralization. First, tone sharing implies that a single tone has spread rightward from one element to the next. In the constructions described, tone spreading would span 
across morpheme and prosodic word boundaries. The spreading would be bounded (only ever spreading by one TBU) yet promiscuous in crossing the aforementioned boundaries. Tone copy, on the other hand, implies the presence of two independent tones on either side of a boundary. Because tone copy avoids the issue of association lines spreading across boundaries, we suggest that it is both analytically and theoretically favorable to assume that tone copy is responsible for the observed outcome, as opposed to sharing (spreading). We shall refer to this henceforth as Neutralization-By-Copy $(\mathrm{NBC})$ to differentiate it from $\mathrm{CT}$. We later discuss further support for this choice and its application in Susu.

\subsection{Neutralization-By-Copy in Susu}

Houis (1963) and Grégoire (1978) describe the tonal outcomes of NBC in Susu; however as we discuss below, they arrive at the same analytical conclusion for only some neutralized forms. ${ }^{8}$

Recall that Susu nouns have three basic tonal melodies, i.e. H, HL, and LH. Houis and Grégoire agree with one another concerning the tonally compact outcomes for $\mathrm{H}$ and LH melodies in (6).

\begin{tabular}{|l|l|l|l|l|}
\hline (6) & a. & HH + XX & $\rightarrow$ & HH.HL \\
\hline & b. & LH + XX & $\rightarrow$ & LL. HL \\
\hline
\end{tabular}

These schema illustrate that if the first element of a compound has a $\mathrm{H}$ tonal melody, the resultant compound will have a HH.HL melody (boundaries are indicated by '.'), regardless of the lexical tonal melody of the second element. Likewise, if the first lexeme has a LH tonal melody, the resultant compound will have a LL.HL melody.

Both outcomes have in common that tonal melody assignment in the larger construction is driven by a left-to-right process stemming from the first input element. In Bambara, the lexical tonal melodies of both elements are neutralized, the first via tone spreading and the second via default tone assignment (followed by spreading, where applicable). In Mende, the lexical melody of the first element is retained, while only that of the second element is neutralized. The data presented thus far demonstrate that Susu behaves similarly, but not identical to Mende, with the apparent exception being the LL melody (6b) found in Susu compounds with a 'low' first element. We assert below, however, that this result is, in fact, predictable and related to a second tonal neutralization process. Before discussing our stance on these points, we consider the behavior of input HL melody words in (7), upon whose behavior Houis and Grégoire disagree.

\begin{tabular}{|l|l|l|l|l|l|}
\hline (7) & a. & For Houis & HL $+\mathrm{XX}$ & $\rightarrow$ & HH.HL \\
\hline & b. & For Grégoire & $\mathrm{HL}+\mathrm{XX}$ & $\rightarrow$ & HL.LH \\
\hline
\end{tabular}

For the compounds in (7), Houis (7a) offers a HH.HL outcome identical to compounds like (6a). Grégoire (7b), however, asserts that the first element of these compounds 
retains its lexical tonal melody; the second morpheme has a LH melody. Grégoire's data are more in line with those observed for Mende in (5), where a first element retains its lexically-specified tonal melody, while its final lexical tone copies to the first TBU of the second element. Some additional mechanism is necessary to explain Houis' data. In order to weigh in on this discrepancy, we collected a variety of compounds drawn from those in Touré (1994:103-106). The tokens collected comprise a variety of word shapes including mainly noun+noun compounds, but also some noun+attributive adjective and verb+noun constructions, all of which Touré asserts are tonally compact (i.e. neutralized). We first present representative constructions produced by our Susu speaker in (8) for constructions whose first element is HH (8a-m) or LH (8n-y). ${ }^{9}$

\begin{tabular}{|c|c|c|c|c|c|c|}
\hline \multirow[t]{2}{*}{ (8) } & \multicolumn{5}{|c|}{ HH first element } & \\
\hline & a. & /bálán + sèé/ & $\rightarrow$ & [bálánséè] & 'seashore' & \\
\hline & & sea + mouth & & & & \\
\hline & b. & /bárí + mìxíí/ & $\rightarrow$ & [bárímíxì] & 'parent' & \\
\hline & & to be born + person & & & & \\
\hline & c. & /dźć + fòxúíi/ & $\rightarrow$ & [déćfóxi] & 'bitemark' & \\
\hline & & mouth + trace & & & & \\
\hline & d. & /déć + kírì/ & $\rightarrow$ & [déćkírìi] & 'lip’ & \\
\hline & & mouth + skin & & & & \\
\hline & e. & /déć + xàbéè/ & $\rightarrow$ & [déćxábè] & 'beard' & \\
\hline & & mouth + hair & & & & \\
\hline & f. & /dع́gé + sèé/ & $\rightarrow$ & [dźgćséè] & 'needle' & \\
\hline & & to sew + thing & & & & \\
\hline & g. & /dîí + yórè/ & $\rightarrow$ & [dííyórè] & 'baby' & \\
\hline & & child + small & & & & \\
\hline & h. & /fiî + fàtéé/ & $\rightarrow$ & [fíífátè] & 'scar' & \\
\hline & & wound + skin & & & & \\
\hline & i. & /fíriíi + fóóré/ & $\rightarrow$ & [firíifóว̀rè] & 'black liana' & \\
\hline & & liana + black & & & & \\
\hline & j. & /yáá + yilîí/ & $\rightarrow$ & [yááyíli] & 'eye socket' & \\
\hline & & eye + hole & & & & \\
\hline
\end{tabular}




\begin{tabular}{|l|l|l|l|l|l|}
\hline & $\mathrm{k}$. & /yźx + xórì/ & $\rightarrow$ & [yéxéxóri] & 'fishbone' \\
\hline & & fish + bone & & & \\
\hline & 1. & /tékú + mààlé/ & $\rightarrow$ & [tékúmáálè] & 'rice produced under \\
\hline & & obligation + rice & & & constraint' \\
\hline & m. & /túgí + yéé/ & $\rightarrow$ & [túgíyéè] & 'palm wine' \\
\hline & & palm tree + water & & & \\
\hline
\end{tabular}

\section{LH first element}

\begin{tabular}{|c|c|c|c|c|}
\hline n. & /bànnáá + mixííi / & $\rightarrow$ & [bànnàmíxì] & 'wealthy (person)' \\
\hline & wealth + person & & & \\
\hline \multirow[t]{2}{*}{ o. } & /bànxí + fárìí/ & $\rightarrow$ & [bànxìfárì] & 'roof' \\
\hline & house + above & & & \\
\hline \multirow[t]{2}{*}{ p. } & /bàré + gìnć/ & $\rightarrow$ & [bàrègínc̀] & 'dog (f.)' \\
\hline & dog + woman & & & \\
\hline \multirow[t]{2}{*}{ q. } & /dòxó + sèé/ & $\rightarrow$ & [dòxòséè] & 'food' \\
\hline & to eat + thing & & & \\
\hline \multirow[t]{2}{*}{ r. } & /fàtéé + fixxé/ & $\rightarrow$ & [fàtèfíxغ̇] & 'European (person)' \\
\hline & skin + white & & & \\
\hline \multirow[t]{2}{*}{ s. } & /fèlén + dùgíî/ & $\rightarrow$ & [fèlèndúgi] & 'blanket' \\
\hline & to cover + cloth & & & \\
\hline \multirow[t]{2}{*}{ t. } & /fintán + sèé/ & $\rightarrow$ & [fintànséè] & 'fan' \\
\hline & to fan + thing & & & \\
\hline \multirow[t]{2}{*}{ u. } & /gغ̀mé + xórì & $\rightarrow$ & [gèmèxórì] & 'pebble' \\
\hline & stone + grain & & & \\
\hline \multirow[t]{2}{*}{ v. } & /gغ̀sć + kúnkì/ & $\rightarrow$ & [gèsc̀kúǹ̀i] & 'weaving shuttle' \\
\hline & thread + pirogue & & & \\
\hline w. & /yiré + nááxí/ & $\rightarrow$ & [yirènááxi] & 'left side' \\
\hline
\end{tabular}




\begin{tabular}{|l|l|l|l|l|l|}
\hline & & place + bad & & & \\
\hline & x. & /kìráá + xùnyí/ & $\rightarrow$ & [kirààxúnì] & 'crossroads' \\
\hline & & road + head & & & \\
\hline & y. & /mààlé + xábé/ & $\rightarrow$ & [mààlèxábè] & 'rice harvester' \\
\hline & rice + to cut & & & \\
\hline
\end{tabular}

The examples in (8) show that our Susu speaker produces tonal melodies matching the schema reported by both Houis and Grégoire for constructions whose first element is either /HH/ or /LH/. Such constructions surface as [HH.HL] and [LL.HL], respectively, confirming previously reported findings.

We now turn to the disputed case of constructions whose first element is underlyingly / $\mathrm{HL} /$, generally speaking. What we mean here is that several reported lexical tone melodies that end in a L tone exhibit a consistent tonal outcome. Note that compounds with a /HL/ first element are considerably less frequent in our (and Touré's corpus). Representative examples are in (9).

\begin{tabular}{|l|l|l|l|l|l|}
\hline (9) & \multicolumn{4}{|c|}{ Compact constructions with a 'HL' first element } \\
\hline & a. & /mángò + xórì/ & $\rightarrow$ & [mángóxòri] & 'mango pit' \\
\hline & & mango + bone & & & \\
\hline & b. & /nááli + mìxíí/ & $\rightarrow$ & [náálímììi] & 'public nuisance' \\
\hline & & tape worm + person & & & \\
\hline & c. & /píyà + bìili/ & $\rightarrow$ & [píyábilì] & 'avocado tree' \\
\hline & & avocado + trunk & & & \\
\hline & d. & /dòndólì + tèć/ & $\rightarrow$ & [dòndólítè] & 'ant hill' \\
\hline & & ant + nest & & & \\
\hline & e. & /bànáánì + bílì/ & $\rightarrow$ & [bànááníbìlì] & 'banana tree' \\
\hline & banana + (tree) trunk & & & \\
\hline
\end{tabular}

The examples in (9) show a consistent tonal outcome with two permutations. In (9a-c), the first element surfaces with all $\mathrm{H}$ tones, while the second element has all $\mathrm{L}$ tones. Examples (9d-e) are more complex due to the shape of the first input element, but as we suggest below, their tonal outcomes follow from the same generalization. The examples in (10) show compounds whose first element also has a final lexical L tone. These inputs comprise a more diverse variety of word shapes and lexical tonal melodies but follow the same general pattern as in (9). We discuss the two sets of words in turn. 


\begin{tabular}{|c|c|c|c|c|c|}
\hline (10) & a. & /sàràsóò + sèé/ & $\rightarrow$ & [sàràsóósèè] & 'purchase' \\
\hline & & purchase + thing & & & \\
\hline & b. & /tábéè + xórì/ & $\rightarrow$ & [tábééxòri] & 'femur' \\
\hline & & buttocks + bone & & & \\
\hline & c. & /yc̀xćc̀ + gìnć/ & $\rightarrow$ & [yèxx́ććgìnè] & 'ewe' \\
\hline & & sheep + woman & & & \\
\hline & d. & /yغ̀xéč + kòntónyí/ & $\rightarrow$ & [yèx ććkòntòjì] & 'ram' \\
\hline & & sheep + male & & & \\
\hline & e. & /yغ̀xćc̀ + yórc̀ / & $\rightarrow$ & [yèxx́ććyว̀rદ̀] & 'lamb' \\
\hline & & sheep + small & & & \\
\hline & f. & /kòòkóò + xórì/ & $\rightarrow$ & [kòòkóóxòrì] & 'cocoa nut' \\
\hline & & cocoa + bone & & & \\
\hline
\end{tabular}

We begin by offering the following schema (11c) alongside those proposed by Houis and Grégoire.

\begin{tabular}{|l|l|l|l|l|l|}
\hline$(11)$ & a. & For Houis & HL + XX & $\rightarrow$ & HH.HL \\
\hline & b. & For Grégoire & HL + XX & $\rightarrow$ & HL.LH \\
\hline & c. & Proposed here & HL + XX & $\rightarrow$ & HH.LL \\
\hline
\end{tabular}

At first glance, it appears that our findings only complicate matters by introducing yet a third schema for constructions with a /HL/ first element. We discuss in the next section, however, that our outcomes follow from the same principles underlying constructions with both / $\mathrm{HH} /$ and /LH/ melodies, upon which our observations converge with Houis and Grégoire (cf. 8). We also propose some possibilities as to how and why the three outcomes in (11) may have arisen.

\subsection{Accounting for tonal alternations}

Data in (8) and (9) show several tonal alternations. We propose that some of these are analogous (at a surface tonal level) to those observed in Manding. For example, the $\mathrm{LH}$ noun /giné/ in (12a) has a LL melody [gìnż] when followed by a H-tone word. This is similar to affaissement (AFF) in Bambara (12b), where a /LH.H/ sequence becomes [LL.H] in the presence of an intervening boundary (Green 2010; Leben 2003). AFF does not occur when a $\mathrm{LH}$ sequence is followed by a $\mathrm{L}$ word. 


\begin{tabular}{|l|l|l|}
\hline (12) & \multicolumn{2}{|l|}{ a. Susu disyllabic words (nb. /gìné/) } \\
\hline & [gìnc̀ fájì] & 'good woman' \\
\hline & [gìnć bèlèbélè] & 'big woman' \\
\hline & b. Bambara disyllabic words (nb. /mùsó/) \\
\hline & [mùsò tć] & 'It is not a woman.' \\
\hline & [mùsó dòn] & 'It is a woman.' \\
\hline
\end{tabular}

Leben $(2002,2003)$ and Green $(2010)$ argue that $L$ tone spreading via AFF occurs within a tonal foot. ${ }^{10}$ What occurs in $(8 \mathrm{n}-\mathrm{z})$, where an input /LH/ first element surfaces [LL] in a compound construction, appears similar. If Susu shares certain prosodic characteristics with its Manding cousins, this outcome suggests that Susu also has tonal feet. Take for example (8u): /gغ̀mé + xórì/ $\rightarrow$ [gèmèxóri] 'pebble'. If Susu has tonal feet like Bambara, the L tone of ( $\mathrm{g} \dot{\varepsilon} . \mathrm{m} \varepsilon)$ spreads rightward within the tonal foot when the word is

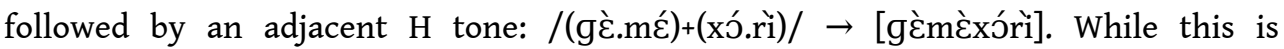
straightforward for constructions like ( $8 \mathrm{u})$, we must address the fact that a [LL] melody results on the first element in all instances, even when the lexical tonal melody of the second element is /LH/. We propose that because multiple, interacting tonal processes occur in Susu (Vydrine 2002), a dynamic result is possible.

We showed in (6) that Susu NBC is generally like tonal neutralization processes in Southwest Mande languages, i.e. the final lexical tone of the first /HH/ or /LH/ element of a compound copies to the first TBU of the following element. This fact, and outcomes like (12a), suggest that NBC provides an appropriate environment for tone spreading via AFF. In generative phonological terms, NBC feeds AFF. Using (8s) as an example: Input /(fè.lén) + (dù.gìi) / $\rightarrow \mathrm{NBC}$ (fè.lén) + (dú.gìi) $\rightarrow$ AFF (fè.lèn) + (dú.gìi) $\rightarrow$ Output [fèlèndúgì]. We discuss these details and their implications further below.

We next illustrate that an alternation analogous to AFF is observed in (13), where HL nouns like /kéri/ have a HH melody [kérí] when followed by a L word.

\begin{tabular}{|l|l|l|l|l|l|}
\hline (13) & a. & /kérì bèlèbélé/ & $\rightarrow$ & [kérí bèlèbélè] & 'big hoe' \\
\hline & b. & /kérì fánỳi/ & $\rightarrow$ & [kérì fánì] & 'good hoe' \\
\hline
\end{tabular}

In (13), /HL.L/ becomes [HH.L] under the same conditions as AFF. This appears to be another instantiation of largely the same process, motivated by the same principles as AFF. That is, in the presence of a boundary, $\mathrm{H}$ tone spreads within a defined domain. However, rather than tone settling (i.e. AFF), the process here is tone raising (RAI). Again, the domain of application appears to be a tonal foot. RAI affects $\mathrm{H}$ tones and has implications for the outcomes in (9), i.e. constructions whose first input element has a lexical melody ending in a L tone. For example (9a): /mángò + xórì $\rightarrow$ [mángóxòrì] 'mango pit'. Because Susu exhibits NBC elsewhere, this would explain why the final lexical L of /mángò/ copies to the first TBU of the adjacent morpheme. If, like the 
relationship between NBC and AFF, NBC feeds RAI, there is a principled reason for why the lexical H of /mángò/ spreads within a foot to yield a [HH.LL] melody. susceptible to varied outcomes than those reported for first element /HH/ and /LH/ constructions. As we have seen, Houis (1963) reports the same HH.HL compact melody for both / $\mathrm{HH} /$ and /HL/ inputs. It may be the case for Houis' Susu speakers that although both NBC and RAI occur within their phonology, the former process became over-generalized. That is, if NBC occurs first, followed by RAI, a disyllabic /HL/ noun followed by another disyllabic word would first yield |HL.LL| as a result of NBC, and then [HH.LL] as a result of RAI. If speakers began to over-generalize the process, it could be that NBC would apply again to this outcome. The result would be HH.LL $\rightarrow$ HH.HL; precisely the outcome reported by Houis. 

melody. The final $\mathrm{H}$ tone is perhaps anomalous (it is the only reported melody with a final $\mathrm{H}$ ), yet the retention of $\mathrm{HL}$ on the first element is less surprising. It is possible that for Grégoire's Susu speakers, although NBC readily applied, RAI simply did not. It may be that RAI is a more recently introduced innovation compared to its analog, AFF. ${ }^{15}$ This may also help to explain its inconsistent application among Susu speakers. The extent to which RAI pervades different populations of Susu speakers must remain open pending further research.

Thus far, we have discussed tonal alternations in Susu compound constructions and entertained them alongside earlier proposals. In addition to providing a schema by which to account for these constructions, we offered some possible reasons for noted discrepancies in the literature related to the behavior of words with certain lexical tonal melodies. For comparison, we next turn to the tonal outcomes for particular noun+modifier $(\mathrm{N}+\mathrm{M})$ constructions.

\section{Noun + Modifier constructions}

Compared to what is known about tone in Susu nominal compounds, relatively little detail is known about how tone functions in other nominal constructions. We offer a look at this via data we have collected on particular noun+modifier constructions. Touré (1994:103-106) describes a variety of $\mathrm{N}+\mathrm{M}$ constructions as 'tonally compact' (i.e. $\mathrm{NBC}$ ) forms. We illustrate below, however, that not all apparent $\mathrm{N}+\mathrm{M}$ constructions follow this pattern. Consider the outcome of nouns representing five lexical tonal melodies followed by two sets of modifiers in (14) and (15).

\begin{tabular}{|c|c|c|c|c|}
\hline \multirow[t]{2}{*}{ (14) } & \multicolumn{4}{|l|}{ a. $\mathrm{HH}$ nouns } \\
\hline & i. /túlí bèlèbélé/ & $\rightarrow$ & [túlí bèlèbélè] ${ }^{16}$ & 'big ear' \\
\hline & ii. /túlí fányì/ & $\rightarrow$ & [túlí fánì] & 'good ear' \\
\hline & iii. /bálé síyà/ & $\rightarrow$ & [bálé síyà] & 'few rats' \\
\hline & iv. /bálé xúrì/ & $\rightarrow$ & [bálé xúrì] & 'small rat' \\
\hline & v. /néné kwî̀)/ & $\rightarrow$ & [nénć kwiè] & 'tall mouse' \\
\hline & vi. /nćné xùngbé/ & $\rightarrow$ & [nénć xùngbè & ]'fat mouse' \\
\hline & vii. /nع́nع́ gbò/ & $\rightarrow$ & [nénć gbò] & 'many mice' \\
\hline & \multicolumn{4}{|l|}{ b. HL nouns } \\
\hline & i. /kérì bèlèbélé/ & $\rightarrow$ & [kérí bèlèbélè] & 'big hoe' \\
\hline & ii. /kérì fányi/ & $\rightarrow$ & [kéri fápii] & 'good hoe' \\
\hline & iii. /síli síyà/ & $\rightarrow$ & [síli síyà] & 'few elephants' \\
\hline
\end{tabular}




\begin{tabular}{|c|c|c|c|}
\hline iv. /síli xúrì/ & $\rightarrow$ & [síli xúrì] & 'small elephant' \\
\hline v. /sćgè kwí̀)/ & $\rightarrow$ & [sćgè kwiè] & 'tall hawk' \\
\hline vi. /sćgè xùngbé/ & $\rightarrow$ & [sćgé xùngbè] & 'fat hawk' \\
\hline vii. /sćgદ̀ gbò/ & $\rightarrow$ & [sćgé gbò] & 'many hawks' \\
\hline \multicolumn{4}{|l|}{ c. LH nouns } \\
\hline i. /gìné bèlèbélé/ & $\rightarrow$ & [gìné bèlèbélè] & 'big woman' \\
\hline ii. /gìné fányi/ & $\rightarrow$ & [gìnè fájì] & 'good woman' \\
\hline iii. /yčtéć síyà/ & $\rightarrow$ & [yc̀tè síyà] & 'few lions' \\
\hline iv. /yc̀tćć xúrì/ & $\rightarrow$ & [yc̀tc̀ xúrì] & 'small lion' \\
\hline v. /kùlé kwíì/ & $\rightarrow$ & [kùlè kwî̀e] & 'tall monkey' \\
\hline vi. /kùlé xùngbé/ & $\rightarrow$ & [kùlé xùngbè] & 'fat monkey' \\
\hline vii. /kùlé gbò/ & $\rightarrow$ & [kùlé gbò] & 'many monkeys' \\
\hline \multicolumn{4}{|l|}{ d. L $\overparen{\text { HL }}$ nouns } \\
\hline i. /yغ̇xćc̀ bèlèbélé/ & $\rightarrow$ & [yغ̀xć bèlèbélè] & 'big sheep' \\
\hline ii. /yèxćc̀ fányì/ & $\rightarrow$ & [yc̀xé 'fánì] & 'good sheep' \\
\hline iii. /yčxćc̀ síyà/ & $\rightarrow$ & [yèxé !síyà] & 'few sheep' \\
\hline iv. /yèxźċ xúrì/ & $\rightarrow$ & [yc̀x ć 'xúrì] & 'small sheep' \\
\hline v. /yèxćc̀ kwî̀/ & $\rightarrow$ & [yc̀x ć !kwî̀] & 'tall sheep' \\
\hline vi. /yغ̀xéč xùngbé/ & $\rightarrow$ & [yèxé xùngbè] & 'fat sheep' \\
\hline vii. /yèxćc̀ gbò/ & $\rightarrow$ & [yèxé gbò] & 'many sheep' \\
\hline \multicolumn{4}{|l|}{ e. LHL nouns } \\
\hline i. /xùnsćxદ̀ bèlèbélé/ & $\rightarrow$ & [xùnsćxć bèlèbélè] & 'big hair' \\
\hline ii. /xùnsćxغ̀ fányì/ & $\rightarrow$ & [xùnsćxغ̀ fápì] & 'good hair' \\
\hline iii. /kònkórè síyà/ & $\rightarrow$ & [kònkórè síyà] & 'few roosters' \\
\hline iv. /kònkórè xúrì/ & $\rightarrow$ & [kònkórè xúrì] & 'small rooster' \\
\hline v. /kònkórè kwiè/ & $\rightarrow$ & [kònkórè kwî̀è] & 'tall rooster' \\
\hline vi. /kònkórè xùngbé/ & $\rightarrow$ & [kònkóré xùngbè] & 'fat rooster' \\
\hline
\end{tabular}




\begin{tabular}{|l|l|l|l|l|}
\hline & vii. /kònkórè gbò/ & $\rightarrow$ & [kònkóré gbò] & ‘many roosters' \\
\hline
\end{tabular}

Most nouns followed by modifiers in (14) largely retain their lexically-specified tonal melody; exceptions include nouns affected by RAI and AFF. Examples in (14d) are different due to the length of the final vowel of the noun being neutralized. While the stable, floating $\mathrm{L}$ tone is not noticeably expressed, its presence is clear where it blocks AFF and induces downstep on an adjacent $\mathrm{H}$. Examples in (14e) support our earlier observation that feet are constructed from the right edge of a word, as RAI looks to have applied. The tonal melodies of these modifiers, however, are static. The outcome is much different when nouns are followed by the modifiers in (15).

\begin{tabular}{|c|c|c|c|c|}
\hline \multirow[t]{2}{*}{ (15) } & \multicolumn{4}{|l|}{ a. HH nouns } \\
\hline & i. /túlí lànmáá/ & $\rightarrow$ & [túlí lámmàà] & 'small ear' \\
\hline & ii. /лźnć dî/ & $\rightarrow$ & [nénć di] & 'little mouse' \\
\hline & iii. /bálé dí/ & $\rightarrow$ & [bálé dî] & 'little rat' \\
\hline & iv. /Jńné yórè/ & $\rightarrow$ & [néné yórè] & 'tiny mouse' \\
\hline & v. /bálé yórè/ & $\rightarrow$ & [bálé yórè] & 'tiny rat' \\
\hline & vi. /káábé gbégbé/ & $\rightarrow$ & [káábé gbégbè] & 'many (ears) of corn' \\
\hline & \multicolumn{4}{|l|}{ b. HL nouns } \\
\hline & i. /kérì lànmáá/ & $\rightarrow$ & [kérí làmmàà] & 'small elephant' \\
\hline & ii. /sílì dí/ & $\rightarrow$ & [sílí dì] & 'little elephant' \\
\hline & iii. /sźgغ̀ dí/ & $\rightarrow$ & [sćgé di] & 'little hawk' \\
\hline & iv. /sílì yórè/ & $\rightarrow$ & [sílí yòrè] & 'tiny elephant' \\
\hline & v. /sćgદ̀ yórè/ & $\rightarrow$ & [sćgé yòrz̀] & 'tiny hawk' \\
\hline & vi. /sílì gbégbé/ & $\rightarrow$ & [sílí gbègbè] & 'many elephants' \\
\hline & \multicolumn{4}{|l|}{ c. LH nouns } \\
\hline & i. /giné lànmáá/ & $\rightarrow$ & [ginè lámmàà] & 'small woman' \\
\hline & ii. /yc̀tćć dí/ & $\rightarrow$ & [yc̀t c̀ di] & 'little lion' \\
\hline & iii. /kùlé dí/ & $\rightarrow$ & [kùlè di] & 'little monkey' \\
\hline & iv. /xùùjé yórè/ & $\rightarrow$ & [xùùnc̀ yórè] & 'tiny toad' \\
\hline & v. /kùlé yórè/ & $\rightarrow$ & [kùlè yórè] & 'tiny monkey' \\
\hline
\end{tabular}




\begin{tabular}{|c|c|c|c|}
\hline vi. /xàmé gbégbé/ & $\rightarrow$ & [xàmè gbégbè] & 'many men' \\
\hline \multicolumn{4}{|l|}{ d. L $\widetilde{\text { HL }}$ nouns } \\
\hline i. /jèxćc̀ lànmáá/ & $\rightarrow$ & [jèxé làmmàà] & 'small lamb' \\
\hline ii. /jèxع́c̀ dí/ & $\rightarrow$ & [jèxé dì] & 'little lamb' \\
\hline iii. /kòòlóò yórc̀/ & $\rightarrow$ & [kòòlóó yòrè] & 'tiny chameleon' \\
\hline iv. /kòòlóò gbégbé/ & $\rightarrow$ & [kòòlóó gbègbè] & 'many chameleons' \\
\hline \multicolumn{4}{|l|}{ e. LHL nouns } \\
\hline i. /xùnsćxè lànmáá/ & $\rightarrow$ & [xùnsćxé làmmàà] & 'small hair' \\
\hline ii. /kònkórè dí/ & $\rightarrow$ & [kònkóré di] & 'little rooster' \\
\hline iii. /kònkórè yórè/ & $\rightarrow$ & [kònkóré yòrc̀] & 'tiny rooster' \\
\hline iv. /xùnséxè gbégbé/ & $\rightarrow$ & [xùnsćxé gbègbè] & 'many hairs' \\
\hline
\end{tabular}

In (15), the first TBU of the modifier appears to have undergone NBC, which then provides the triggering environment for AFF and RAI, where applicable. The tonal outcomes of these particular constructions are markedly different from the static, nonalternating tonal melodies observed on modifiers in (14). This suggests, therefore, that 'adjectival' modifiers do not behave uniformly in $\mathrm{N}+\mathrm{M}$ constructions. Rather, the modifiers in some $\mathrm{N}+\mathrm{M}$ constructions as in (15) are best considered nouns, causing the constructions to behave tonally as compounds. Other $\mathrm{N}+\mathrm{M}$ constructions as in (14) do not behave tonally as compounds, suggesting that their modifiers are properly considered adjectives. While only the former are susceptible to NBC, AFF and RAI appear to be more general processes, applying in both types of construction, i.e. whenever appropriate conditions are met. While these data are not exhaustive, they nonetheless provide an additional layer of detail about Susu nominal constructions not yet discussed in the extant published literature.

\section{Discussion}

This paper aimed to accomplish several goals. First, our data on compounds shed new light on a longstanding discrepancy in the Susu literature on the tonal outcome of constructions whose first element is lexically /HL/. The tonal behavior of these and other constructions allows us to illustrate with certainty that the tonal neutralizations observed in Susu are aligned with those found in Southwest Mande. We have also offered some evidence for two additional, complementary tonal processes in Susu, affaissement and raising, that appear to have a domain of application characteristic of a tonal foot. To our knowledge, this is the first discussion of higher prosodic structure in the Susu literature. Further research is necessary to explore systematically the extent to which other tonal (or segmental) phenomena reference this domain in Susu. Finally, we presented data on noun+modifier constructions illustrating that some behave like 
compounds in permitting NBC, while others disallow the process. All such constructions, however, appear susceptible to both AFF and RAI. While Touré (2004) provides several examples of possible nominal constructions, we are aware of no other work discussing their tonal behavior in this way.

\subsection{Formalizing NBC} Creissels (2009). The premise of this approach is that a language's marked tone is lexically-specified; other tones are supplied by default after the application of tone spreading rules. As the reviewer points out, Bambara is a well-known yet atypical case of a language with a marked L vs. unmarked $\mathrm{H}$ tone system. It has been argued that Bambara's lexically-assigned, marked $\mathrm{L}$ tone spreads within a particular domain under certain conditions, after which $\mathrm{H}$ tones are supplied by default; this is offered as an explanation for its distribution of tonal melodies and certain tonal neutralization processes in the language (Creissels 2009:22-39). Furthermore, the reviewer points out that tonal neutralization in Mende could be attributed to an analogous case of marked $\mathrm{H}$ tone spreading followed by the insertion of $\mathrm{L}$ tones by default. While it may be possible to postulate some variation on this analysis for Susu, this option is not without complications.

A pertinent issue in a markedness analysis of Susu lies in the fact that both its tones exhibit characteristics of 'marked' tones in other languages. For example, as in Mende, Susu's $\mathrm{H}$ tone spreads (for the sake of arguing this point of view) in compound formation: $\mathrm{HH}+\mathrm{XX} \rightarrow \mathrm{HH}+\mathrm{HL}$. This is characteristic of the marked $\mathrm{H}$ tone in Mende. Recall, however, that L tone will also spread in Susu under certain conditions: $\mathrm{LH}+\mathrm{XX} \rightarrow$ LL+HL. This is characteristic of the marked L tone in Bambara. The clarity of such an analysis unfortunately decreases with these conflicting parameters. It may be possible, 
however, to appeal to a marked $\mathrm{H}$ analysis for Susu if, when a $\mathrm{H}$ tone were to spread in compound formation, it would subsequently delink from its lexically-associated TBU. If this were to occur after default tones had been assigned, it may be plausible that a $\mathrm{L}$ tone would spread to fill the newly vacant mora or another supplied by default. A less problematic issue is that the $\mathrm{H}$ tone of lexical HL nouns also spreads in compound formation, yet does not appear to delink: $\mathrm{HL}+\mathrm{XX} \rightarrow \mathrm{HH}+\mathrm{LL}$. This analysis would also suffer from the shortcomings mentioned above concerning the atypicality of nonphonologically-motivated tone spreading and tone spread across a boundary.

Another possibility is that NBC is a prosodic process triggered by compounding. If a word's lexical tonal melody is a property of the prosodic word domain, upon compounding via adjunction, the melody could percolate to a higher prosodic word projection with scope over a larger, yet singular domain. This would, at the least, bypass the issue of boundary crossing and would provide a morphophonological explanation for the tonal process. This would also provide a principled reason why only certain constructions (i.e. those whose elements are dominated by a single prosodic word maximal projection) are subject to the process. Constructions failing to meet this condition (e.g. noun+modifier constructions in (14)) disallow the process. Exploring the extent to which these various analyses apply to Susu will require further research on constructions and words of many additional types.

\subsection{Interactions and opacity}

The application and interaction of tonal processes in Susu, particularly in constructions that permit both NBC and AFF/RAI, present an interesting anomaly. That is, if Susu learners rely on the fact that NBC has occurred to provide evidence that two elements are in a compound relationship, this evidence is obscured by the subsequent application of AFF/RAI. With the exception of compounds whose first element is lexically $\mathrm{HH}$, other compounds (i.e. those whose first element is /LH/ or /HL/ and susceptible to AFF or RAI) result in surface tonal melodies where NBC appears to have underapplied. This is clear in instances like /LH $+\mathrm{XX} / \rightarrow[\mathrm{LL} . \mathrm{HL}]$ and /HL $+\mathrm{XX} / \rightarrow$ [HH.LL] where the surface tone on the final TBU of the first element does not match the tone of the following TBU. Although we have shown that both NBC and AFF/RAI apply transparently, their combined outcome is opaque in that, at the phonetic level, it appears that NBC has not occurred. We proposed above that this opacity may have led to overgeneralization of $\mathrm{NBC}$, resulting in the conflicting surface tonal melodies reported in the literature for some constructions. It is unlikely that overgeneralization would adversely affect $/ \mathrm{LH}+\mathrm{XX} /$ constructions, as there is still adequate evidence to the learner that the first element is /LH/. The situation is different for / $\mathrm{HL}+\mathrm{XX} /$ where the lexical tonal melody of the first element is obscured. This could (over time) lead to the relexicalization of / $\mathrm{HL} /$ words as $/ \mathrm{HH} /$.

\section{Concluding remarks}

These findings and data suggest that a systematic exploration into the tonal behavior of a variety of related constructions (e.g. those briefly introduced in Touré 2004) with equally varied input elements must be undertaken to better understand the extent to which each construction does or does not exhibit i) NBC; ii) AFF and RAI; iii) other 
segmental or tonal processes relying on or affected by prosodic or morphosyntactic structure. Because in related languages a sizable majority of constructions can be tonally neutralized (e.g. Dumestre 2003:109-126), it is of typological interest to explore the tonal behavior of related constructions in Susu. Grégoire (1978) has already shown that Susu $\mathrm{N}+\mathrm{N}$ compounds in which the head noun is a semantic agent have an entirely different tonal behavior compared typical $\mathrm{N}+\mathrm{N}$ compounds. This suggests, as argued for in other Mande languages, that tonal neutralization processes are dependent on multiple components of a language's grammar, including its morphosyntax (Bamba 1991; Creissels 1992) and its morphophonology (Green 2010, 2013).

51 These endeavors fit into a larger exploration into the distribution and application of tonal neutralization processes in Mande languages and beyond. It is well-documented that tonal neutralization is characteristic of Manding languages (e.g. Bambara, Malinké, and Dyula), other Central Mande languages (e.g. Susu and Dialonké), and Southwest Mande languages (e.g. Mende, Zialo, Kpelle, Looma, among others). Recent work reports that analogous processes are found in languages like Tigemaxoo Bozo, a Northwest Mande language (Blecke 2011), and in several Dogon languages (McPherson forthcoming), both of which are spoken in Mali. Although the details are unfolding, one must ask if these processes are, in fact, an areal feature of these language groups in close contact. There is much to be gleaned from work on languages of this area whose tonal systems are underdocumented, among them Kono, Kakabe, Kuranko, Mixifore, Jahanka, and several others.

In conclusion, what we have done in this paper is to provide new data on Susu in order to gain insight into the tonal processes that influence the surface tonal melodies found in the language. We have drawn upon earlier data and analyses discussing tone in nominal compounds and have illustrated that the tonal melodies associated with Noun + Modifier constructions, while predictable, are not subject to the same tonal neutralization process observed elsewhere in Susu. This paper, therefore, provides the impetus to explore the extent to which related nominal and verbal constructions follow one or the other of these two patterns, or perhaps a unique pattern of their own. This paper also adds to a growing body of work focused on the role of metrical or prosodic feet in segmental processes and tone assignment in Mande languages (e.g. Bamba 1991; Green 2010, 2013; Green, Davis, Diakite \& Baertsch 2012; Leben 2002, 2003; Vydrine 2002, 2010; Weidman \& Rose 2006).

\section{BIBLIOGRAPHY}

BABAEV Kirill, 2010, Zialo: The newly-discovered Mande language of Guinea, Munich, LINCOM Europa.

BAMBA Moussa, 1991, De l'interaction entre tons et accent, Doctoral dissertation, Université du Québec à Montréal.

BLECKE Thomas, 2011, Incorporation in Tigemaxoo, Paper presented at the $3^{\text {rd }}$ Colloque Mandé. Paris, France. 
COURTENAY Karen, 1974, "On the nature of the Bambara tone system", Studies in African Linguistics, 5(3), 303-323.

CREISSELS Denis, 1988, Le système tonale du bambara standard, Grenoble, Centre de Linguistique Africaines de l'Université Stendhal.

CREISSELS Denis, 1992, « Tonologie du bambara standard: Bilan et perspectives », Mandenkan 24, 1-45.

CREISSELS Denis, 2009, Le malinké de Kita: Un parler mandingue de l'ouest du Mali, Köln, Rüdiger Köppe. CREISSELS Denis, GRÉGOIRE Claire, 1993, « La notion de ton marqué dans l'analyse d'une opposition tonale binaire: Le cas du mandingue ", Journal of African Languages and Linguistics 14, 107-154. DIAGANA Yakouba, 1990, « La tonalité du constituent nominal en soninke », Mandenkan 19, 13-37. DWYER David, 1971, “Mende tone”, Studies in African Linguistics, 2(2), 117-130.

DWYER David, 1978a, “What sort of tone language is Mende?" Studies in African Linguistics, 9(2), 167-208.

DWYER David, 1978b, “Idiosyncratic, suprasegmental processes in Mende”, Studies in African Linguistics, 9(3).

DUMESTRE Gerard, 1987, Le bambara du Mali: Essais de description linguistique, Thèse d'état, Sorbonne nouvelle, Paris.

DUMESTRE Gerard, 2003, Grammaire fondamentale du Bambara, Paris: Karthala.

GREEN Christopher R., 2010, Prosodic phonology in Bamana (Bambara): Syllable complexity, metrical structure, and tone, Ph.D. dissertation, Indiana University.

GREEN Christopher R., 2013, "Formalizing the prosodic word domain in Bambara tonology", Journal of West African Languages, 40(1), 3-20.

GREEN Christopher R., DAVIS Stuart, DIAKITE Boubacar, BAERTSCH Karen, 2012, "Domain-restricted reduction: A proposal for segmental feet in Bamana", in Bruce CoNNELL and Nicholas RolLE (eds.), Selected Proceedings of the $41^{\text {st }}$ Annual Conference on African Linguistics: African Languages in Contact, Somerville (MA), Cascadilla Proceedings Project, 1-9.

GRÉGOIRE Claire, 1978, « La tonalité des mots composés et celle du present progressif en soso », Journées d'études langue et linguistique manding 1, 75-86.

HOUIS Maurice, 1963, Étude descriptive de la langue susu, Mémoires de l'IFAN, 67. Dakar, IFAN.

HYMAN Larry, 1978, “Historical tonology”, in Victoria A. FROMKIN (ed.), Tone: A linguistic survey, New York, Academic Press, 257-269.

HYMAN Larry, 2007, “Universals of tone rules: 30 years later", in Tomas RIAD \& Carlos GUSSENHOVEN (eds.), Tones and tunes: Studies in word and sentence prosody, Berlin, Mouton de Gruyter, 1-34.

KEITA Boniface, 1989, « La compacité tonale en Dialonké », Mandenkan 18, 61- 68.

KONOSHENKo Maria, 2008, "Tonal systems in three dialects of the Kpelle language”, Mandenkan 4, 21-42.

KONOSHENKo Maria, 2011, “Tonal systems in the dialects of Kpelle”, BA thesis, Saint Petersburg. LEBEN William R., 1973, Suprasegmental phonology, Ph.D. Dissertation, Massachusetts Institute of Technology, Distributed by IULC Publications. 
LEBEN William R., 1978, “The representation of tone”, in: V. A. FROMKIN (ed.) Tone: A linguistic survey, New York, Academic Press, 177-219.

LEBEN William R., 2002, “Tonal feet”, in, Ulrike GUT \& Dayfdd GIBBON (eds.), Proceedings, typology of African prosodic systems, Vol. 1. Bielefeld, Germany, Bielefeld Occasional Papers in Typology, 129-138.

LEBEN William R., 2003, “Tonal feet as tonal domains", in: John MUGANE (ed.), Trends in African Linguistics 5: Linguistic typology and representation of African languages, Trenton, Africa World Press, 129-138.

MCPHERSON Laura, (forthcoming), Replacive grammatical tone in the Dogon languages: A factorial typology, Ph.D. dissertation, University of California-Los Angeles.

MISHCHENKO Daria, 2009, “Tonal system of LJoma language: The Woi-Balagha dialect”,

Mandenkan 45, 3-16.

NESPOR Marina, VOGEL Irene, 1986, Prosodic phonology, Dordrecht, Foris.

RIALLAND Annie, 1990, « La structure du système tonal soninke », Linguistique Africaine 5, 49-76.

SADLER Wesley, 2006, “A complete analysis of the Looma language (Interior Liberia, West Africa)”, Mandenkan 42, 5-109.

SANOGO Mamadou Lamine, 1995, « Tons, segments, et règles transformationnelles en jula », Mandenkan 30, 41-54.

schuH Russell G., 1978, “Tone rules”, in: V. A. FROMKIN (ed.) Tone: A linguistic survey, New York, Academic Press, 221-256.

SELKIRK Elisabeth, 1984, Phonology and Syntax: The relation between sound and structure, Cambridge (MA), MIT Press.

SPEARS Richard A., 1967, Basic course in Mende, Evanston (IL), Northwestern University.

TOURÉ Aboubacar, 1994, Éléments de description de la langue soso, Thèse de doctorat, Université Stendhal Grenoble III.

TOURÉ Aboubacar, 2004, Parlons Soso, Paris, L’Harmattan.

VYDRINE Valentin, 1989, “Tonal system of the Looma language”, Mandenkan 18, 81-98.

VYDRINE Valentin, 2002, "Some hasty notes on the ways of the evolution of Mande tonal systems", in R. NICOLAI and P. ZIMA (eds.), Lexical and structural diffusion, Publications de la Faculté des Lettres, Arts et Sciences Humaines, Université de Nice et de la Faculté des Etudes Humaines, Université Charles de Prague. Série: Corpus, Les Cahiers 1, 243-264.

VYDRINE Valentin, 2010, « Le pied métrique dans les langues mandé », in Franck Floricic (Ed.), Essais de typologie et de linguistique générale: Mélanges offerts à Denis Creissels, Lyon, ENS Éditions, 53-62.

WEIDMAN Scott, ROSE Sharon, 2006, “A foot-based reanalysis of edge-in tonal phenomena in Bambara", in: Donald BAUMER, David MONTERo \& Michael SCANLON (eds.), Proceedings of the 25th West Coast Conference on Formal Linguistics, Somerville (MA), Cascadilla Proceedings Project, 426-434. WELMERS William E, 1969, “The morphology of Kpelle nominal”, Journal of African Languages, 8(2), 73-101. 
WELMERS William E, 1976, A grammar of Vai, Berkeley and Los Angeles, University of California Press.

\section{NOTES}

1. Data were gathered from a 31 year old native Susu speaker from Conakry, Guinea, over a period of 9 months in the US. The speaker is also fluent in French and Maninka.

2. $\mathrm{H}$ and $\mathrm{L}$ refer to High and Low tones, respectively. $\mathrm{H}$ tone is marked by an acute accent, while $\mathrm{L}$ tone is marked by a grave accent, as conventional. Throughout this paper, 'c' and ' $\mathrm{j}$ ' refer to the voiceless and voiced palatal affricates, $[\mathrm{t}]]$ and [dz], respectively, while ' $\mathrm{y}$ ' refers to the palatal glide [j]. A list of abbreviations used throughout this paper precedes the References.

3. A somewhat different process, although described as compacité tonale, occurs in Soninke. For different viewpoints on Soninke tone, see Diagana (1990) and Rialland (1990).

4. Some scholars (e.g. Dumestre 2003; Green 2010; Leben 2003) consider the majority of Bambara words to be lexically associated with a $\mathrm{H}$ or LH tonal melody, with tonal alternations between $\mathrm{LH}$ and $\mathrm{L}(\mathrm{L})$ in the latter group being the result of a tone assimilation rule. A second perspective, versions of which are explicated in Creissels \& Grégoire (1993) and Creissels (2009), proposes that words are lexically specified only with marked L tones, after which $\mathrm{H}$ tones are introduced by default.

5. For more on constructions and phrases that undergo or fail to undergo CT in Bambara, see Dumestre (2003). For complementary proposals on the roles of morphosyntax and prosodic structure on Bambara CT, see Creissels (1988) and Green (2013), respectively.

6. Keita (1989:63) suggests that this outcome stems from a syntactic re-write rule that first affects the second element of the construction, imposing a $\mathrm{L}$ tone overlay or removing the lexical tone of the element. After this, the final lexical tone of the first element is able to share/copy. We thank an anonymous reviewer for pointing us towards further evidence from Liberian Kpelle supporting Keita (1989), found in Welmers (1969) and Konoshenko (2011).

7. An anonymous reviewer suggests that Mande tonal neutralization processes can also be analyzed by appealing to bounded spreading of marked tones, as outlined in Creissels \& Grégoire (1993) and Creissels (2009). We discuss this further below.

8. Beyond the two neutralization schemas suggested by Houis and Grégoire, Touré $(1994,2004)$ presents a slightly different perspective on the topic. His account approximates that described by Grégoire closely enough, however, that it does not merit independent discussion.

9. We offer lexical tone melodies for each input element with caution. Underlying tonal melodies are not consistently marked in Touré (1994) and oftentimes do not match those later provided in Touré (2004). In instances where we found a discrepancy between sources, we extrapolated the proposed lexical melody from the overall tonal behavior of the compound in relation to others.

10.

A foot refers to a domain or layer in the prosodic hierarchy (e.g. Nespor \& Vogel 1986; Selkirk 1984) that immediately dominates the syllable and is immediately dominated by the prosodic word domain. Feet are most typically binary (either bisyllabic or bimoraic, depending on the language) and project a head; left-headed feet are trochees, while right-headed feet are iambs. The head of a foot often relates to metrical or phonological prominence. In Bambara, Leben $(2002,2003)$ and Green (2010) propose that Bambara feet are maximally disyllabic; however they debate the details of foot headedness. While Green proposes that feet are trochaic in all instances, Leben argues that word headedness is lexically-specified.

11. We thank V. Vydrine (personal communication) for suggesting additional words and word shapes that have influenced this analysis. 
12. We assume that feet are parsed exhaustively. Therefore, degenerate monosyllabic feet result from odd parity inputs. This assumption does not bear in a significant way on the analysis proposed herein.

13. We are aware of words like /kòótáá + mìxíí/ $\rightarrow$ [kòòtààmíxì] 'trickster' (Lit. trick + person) that provide more detail as to the ways that word shapes and tonal processes interact. Here, NBC occurs as expected, copying the final $\mathrm{H}$ of the first element to the first TBU of the second element. It appears that Decontouring acts next, removing the LH contour of the first syllable of the first element. As a result, conditions are right for AFF to apply. For example: Input /kòótáa + mìxìi $\rightarrow \mathrm{NBC}$ (kòó.táá) + (mí.xì) $\rightarrow$ Decontouring (kòò.táá) + (mí.xì) $\rightarrow$ AFF (kòò.tàà) + (mí.xì) $\rightarrow$ Output [kòòtààmíxì].

14. One additional possibility relating to Susu tonal feet concerns headedness. If tonal processes in Susu, such as AFF (and its analog RAI), indeed follow a general left-to-right sequence such that the leftmost tone of a foot has the ability to spread, this may offer preliminary evidence suggesting that tonal feet are binary syllabic trochees.

15. Note that Keita (1989:65) reports free variation between HH.HL and HH.LH for compact forms with a lexically /HL/ first element. These are precisely the competing melodies reported by Houis (1963) and Grégoire (1978). A deeper look at the behavior of Dialonké constructions would be necessary before drawing any conclusions about this state of affairs.

16. A reviewer asks for an explanation of the static, unusual tonal melody of bèlèbélè 'big.' It may be that it stems from the adjective being reduplicated, but we cannot say for certain.

\section{ABSTRACTS}

Susu, like a number of other Mande languages, displays tonal melody neutralization in some nominal constructions. This paper illustrates that in addition to the lexical tonal melody of input elements playing a key role in the outcomes of neutralization, prosodic structure and interactions between multiple tonal processes are also important factors driving observed surface forms. We present novel data on a wide variety of compounds containing complex word shapes; tonal outcomes in such compounds offer a deeper look at factors influencing neutralization. We posit that tones in Susu nominal compounds are subject to Neutralization-byCopy, which subsequently interacts with analogous, more generalized processes that further smooth the overall tonal contours of a given word.

Le soussou, comme certaines autres langues mandé, manifeste la neutralisation tonale dans quelques constructions nominales. Cet article cherche à montrer qu'à part le schéma tonal lexical des éléments dont le rôle est principal pour la neutralisation, la structure prosodique et l'interaction entre des nombreux processus tonals sont également des facteurs importants pour la production des formes de surface. Nous présentons de nouveaux données sur la grande variété des mots composés comportant des formes complexes; les schémas tonales de ces mots composés donnent une vision plus profonde des facteurs qui exercent l'influence sur la neutralisation. Nous supposons que les tons dans les mots composés en soussou subissent la règle de neutralisation par copie, et ensuite ils se soumettent aux processus généraux qui aplatissent les contours tonals des mots. 
В СУСУ, КАК И В НЕКОТОРЫХ ДРУГИХ ЯЗЫКАХ МАНДЕ, ИМЕЕТ МЕСТО НЕЙТРАЛИЗАЦИЯ ТОНАЛЬНЫХ КОНТУРОВ В НЕКОТОРЫХ ИМЕННЫХ КОНСТРУКЦИЯХ. В СТАТЬЕ ПОКАЗАНО, ЧТО НА РЕЗУЛЬТАТ НЕЙТРАЛИЗАЦИИ И НА ПОВЕРХНОСТНЫЕ ТОНАЛЬНЫЕ РЕАЛИЗАЦИИ, ПОМИМО ИСХОДНОГО ТОНА ЭЛЕМЕНТА, ВЛИЯЕТ ТАКЖЕ ПРОСОДИЧЕСКАЯ СТРУКТУРА И ВЗАИМОДЕЙСТВИЕ МЕЖДУ МНОГОЧИСЛЕННЫМИ ТОНАЛЬНЫМИ ПРОЦЕССАМИ. МЫ ВВОДИМ НОВЫЕ ДАННЫЕ ПО МНОГОЧИСЛЕННЫМ ТИПАМ СОСТАВНЫХ СЛОВ, ВКЛЮЧАЮЩИХ В СЕБЯ СЛОЖНЫЕ ФОРМЫ; ТОНАЛЬНЫЕ РЕАЛИЗАЦИИ ТАКИХ СЛОЖНЫХ СЛОВ ПОЗВОЛЯЮТ БОЛЕЕ ГЛУБОКО ВЗГЛЯНУТЬ НА ФАКТОРЫ, ОБУСЛАВЛИВАЮЩИЕ НЕЙТРАЛИЗАЦИЮ. МЫ СЧИТАЕМ, ЧТО ТОНЫ СЛОЖНЫХ СЛОВ В СУСУ ПОДЧИНЯЮТСЯ ПРАВИЛУ НЕЙТРАЛИЗАЦИИ ЧЕРЕЗ КОПИРОВАНИЕ, КОТОРОЕ ВЗАИМОДЕЙСТВУЕТ С АНАЛОГИЧЕСКИМИ БОЛЕЕ ОБЩИМИ ПРОЦЕССАМИ, РЕЗУЛЬТАТОМ ЧЕГО ЯВЛЯЕТСЯ СГЛАЖИВАНИЕ ТОНАЛЬНЫХ КОНТУРОВ СЛОВ.

\section{INDEX}

Keywords: Susu, Tone Neutralization, Compounding, Tonal Melody, Tone Interaction Mots-clés: neutralisation tonale, composition, contour tonal, interaction tonale Subjects: soussou

motsclesru СУСУ, ТОНОВАЯ НЕЙТРАЛИЗАЦИЯ, ОБРАЗОВАНИЕ СЛОЖНЫХ СЛОВ, ТОНАЛЬНЫЙ КОНТУР, ВЗАИМОДЕЙСТВИЕ ТОНОВ

\section{AUTHORS}

\section{CHRISTOPHER R. GREEN}

University of Maryland-CASL

greencr@umd.edu

\section{JONATHAN C. ANDERSON}

Indiana University

andersjc@indiana.edu

\section{SAMUEL G. OBENG}

Indiana University

sobeng@indiana.edu 